\title{
Formulasi Sediaan Krim Pelembab Ekstrak Air Buah Semangka (Citrullus lanatus)
}

\author{
Ni Luh Putu Serly Ekayanti ${ }^{\mathrm{a}^{*}}$, Farida Lanawati Darsono ${ }^{\mathrm{a}}$, Sumi Wijaya ${ }^{\mathrm{a}}$ \\ ${ }^{a}$ Fakultas Farmasi, Universitas Katolik Widya Mandala Surabaya, Surabaya, Indonesia
}

Buah semangka merupakan buah tropis yang kaya akan kandungan karbohidrat jenis gula-gulaan yaitu sukrosa, glukosa dan fruktosa yang dapat berfungsi untuk melembabkan kulit. Adanya kandungan karotenoid seperti lycopene yang dapat berfungsi sebagai antioksidan pada buah semangka juga dapat melindungi kulit dari efek radikal bebas. Pelembab (moisturizer) merupakan sediaan yang digunakan untuk memperbaiki kulit yang kering. Sediaan ini dapat menurunkan Trans Epidermal Water Loss (TEWL) dengan membentuk lapisan lemak tipis di permukaan kulit sebagai barier dan mengembalikan kelembutan kulit. Ekstrak buah semangka pada penelitian ini diformulasikan menjadi sediaan krim pelembab. Penelitian ini bertujuan untuk mengetahui pengaruh konsentrasi ekstrak buah semangka terhadap mutu fisik, efektivitas, keamanan, aseptabilitas dan stabilitas sediaan krim pelembab. Pada penelitian ini, ekstrak yang digunakan berupa perasan buah segar yang dikentalkan dengan thermostat waterbath suhu $\leq 80^{\circ} \mathrm{C}$. Konsentrasi ekstrak buah semangka yang digunakan adalah 10\% (Formula 1), 20\% (Formula 2) dan 30\% (Formula 3). Evaluasi sediaan yang dilakukan meliputi uji mutu fisik; uji efektivitas; uji keamanan; uji aseptabilitas dan uji stabilitas fisik sediaan. Hasil penelitian menunjukan bahwa peningkatan konsentrasi ekstrak kental buah semangka berpengaruh secara signifikan $(\mathrm{P}<0,05)$ terhadap organoleptis, $\mathrm{pH}$, viskositas, daya sebar, daya lekat, daya tercucikan air, daya melembabkan, aktivitas antioksidan dan aseptabilitas. Sediaan yang terbaik adalah sediaan dengan konsentrasi ekstrak $30 \%$ (Formula 3).

Kata kunci: Antioksidan, Citrullus lanatus, Krim pelembab, Sukrosa.

\section{Formulation of Moisturizing Cream Containing the Aqueous Extract of Watermelon (Citrullus lanatus) Fruit}

\begin{abstract}
Watermelon is a tropical fruit which rich of carbohydrates such as sucrose, glucose and fructose that can moisturized the skin. Carotenoids such as lycopene in watermelons can acts as an antioxidant which protected skin from free radicals. Moisturizer are preparations used to improve dry skin. These preparations may decrease the Trans Epidermal Water Loss (TEWL) by forming a thin layer of fat on the surface of the skin as a barrier and restore skin softness. Watermelon extracts in this study are formulated into moisturizing cream. This study aims to determine the effect of the increasing concentration of the watermelon extract against its physical quality, effectiveness, safety, acceptability and cream stability. The watermelon extract obtained using is fresh fruit juice thickened with waterbath thermostat temperature $\leq 80^{\circ} \mathrm{C}$. Watermelon extract concentration used was $10 \%$ (Formula 1), 20\% (Formula 2) and 30\% (Formula 30. Evaluation of the cream includes the physical quality test; effectiveness test which; safety test; acceptability test and stability test. The results of this study showed the increasing concentrations of watermelon extract affect the results of the evaluation of moisturizing cream were organoleptic, pH, viscosity, dispersive power, adhesion, water washing power, effectiveness, and aseptability. Preparations which have the best quality are formula 3 containing extract $30 \%$.
\end{abstract}

Keywords: Antioxidant, Citrullus lanatus, Moisturizer cream, Sucrose.

${ }^{*}$ Corresponding author: Fakultas Farmasi Universitas Katolik Widya Mandala Surabaya, JI. Raya Kalisari Selatan No.1 Surabaya, e-mail: serlyekayanti@gmail.com 


\section{PENDAHULUAN}

Kulit kering merupakan salah satu masalah kulit yang sering dijumpai, dimana kulit kering akan terlihat kusam, permukaan bersisik, kasar dan daerah putih kering merata (Voegeli, 2007). Kulit kering memiliki kadar air dan natural moisturizing factor (NMF) yang lebih rendah daripada kulit normal. Jika terjadi penguapan yang berlebihan mengakibatkan kadar air dalam stratum korneum dapat berkurang hingga 10\% yang dapat mengakibatkan kulit menjadi kering (Rawlings et al., 2000).

Pelembab (moisturizer) merupakan sediaan yang digunakan untuk memperbaiki kulit yang kering. Sediaan ini dapat menurunkan Trans Epidermal Water Loss (TEWL) dengan membentuk lapisan lemak tipis di permukaan kulit sebagai barier, menenangkan ujung saraf dermal, dan mengembalikan kelembutan kulit (Simion, Abrutyn and Draelos, 2005).

Beberapa buah dapat dimanfaatkan menjadi produk pelembab salah satunya yaitu semangka. Namun, pemanfaatan buah semangka sebagai produk kosmetik di pasaran masih jarang ditemukan. Buah semangka mengandung $91,45 \%$ air, o,15\% lemak, 7,55\% karbohidrat, 0,4\% serat, $6,2 \%$ gula, vitamin seperti vitamin C, tiamin, riboflavin dan niasin (United States Department of Agriculture, 2003). Semangka juga kaya akan beberapa karotenoid di antaranya termasuk lycopene, phytofluene, phytoene, beta-karoten, dan lutein. Bahan aktif dalam buah semangka yang berperan sebagai pelembab yaitu karbohidrat jenis gula-gulaan yaitu sukrosa, glukosa dan fruktosa yang merupakan gula utama yang terdapat pada buah semangka (Liu et al., 2013). Sukrosa, glukosa dan fruktosa termasuk golongan humektan, memiliki efek sebagai pelembab karena memiliki gugus hidroksi yang menyebabkan terikatnya air dari udara atau lingkungan sehingga dapat mereduksi penguapan air dalam kulit, sehingga kelembaban kulit akan terjaga (Lubis, Lubis, dan Reveny, 2012).

Penelitian sebelumnya lebih banyak mempelajari mengenai aktivitas antioksidan dari buah semangka dan belum ada penelitian yang mempelajari efektivitas ekstrak buah semangka dalam suatu sediaan krim pelembab dengan mempertimbangkan kandungan gula dalam buah semangka. Menurut Wijaya (1996), senyawa radikal bebas dapat merusak serabut kolagen kulit dan matrik dermis sehingga kulit menjadi kering sehingga penggunaan antioksidan juga baik untuk pencegahan kulit kering. Dengan diperbaikinya struktur kulit, maka kulit dapat mengurangi terjadinya penguapan air dan dengan adanya gula pada ekstrak maka akan dapat membantu menarik air ke dalam kulit dan mengembalikan kelembaban kulit. Oleh karena itu, perlu dilakukan penelitian lebih lanjut terhadap kemampuan ekstrak buah semangka sebagai pelembab dan juga aktivitas antioksidannya untuk memperoleh suatu sediaan yang efektif untuk mengatasi kulit kering.
Penelitian ini bertujuan untuk mengetahui pengaruh peningkatan konsentrasi ekstrak kental buah semangka $(10 \%, 20 \%$ dan 30\%) terhadap mutu fisik, efektivitas, keamanan, aseptabilitas dan stabilitas sediaan krim pelembab.

\section{METODE PENELITIAN Alat}

Alat-alat yang digunakan dalam penelitian ini antara lain neraca analitik (Sartorius BP 110S, Jerman), pH meter (Methrom 620, Switzerland), viscometer Brookfield (Synchro-Letic LVT, USA), spektrofotometer UV-Vis (Hitachi tipe U-1100, Jepang), blender, thermostat waterbath (Memmert, Germany), oven (Memmert, Germany), mortir, stamper, termometer, krus porselen, anak timbangan, alat-alat gelas dan alat penunjang lain.

\section{Bahan}

Bahan yang digunakan pada penelitian ini yaitu buah semangka merah (Surabaya, Jawa Timur), asam stearat (PT. Sumi Asih, Indonesia), gliseril monostearat (Croda Pto Ltd, Singapore), trietanolamin (Loba Chemie PVT, LTD), gliserin (PT. Sumi Asih, Indonesia), propilen glikol (Dow Chemical Pacific, Singapore), metil paraben (Amresco, LLC), propil paraben (Amresco, LLC) dan akuadest (PT. Brataco Chemica, Indonesia), etanol (PT. Brataco Chemica, Indonesia), DPPH (Sigma-Aldrich, Singapore), metanol pa (Mailinckrodt Baker Inc, Philipsburg).

\section{Tahapan Penelitian}

Penyiapan Simplisia Segar

Buah semangka merah segar dicuci bersih, dipisahkan bagian daging buah yang berwarna merah dari kulit dan bijinya. Daging buah kemudian dipotong-potong menjadi bagian yang lebih kecil dan ditimbang untuk mendapatkan beratnya.

\section{Pembuatan Ekstrak Kental Buah Semangka}

Simplisia segar dihaluskan dengan menggunakan blender, kemudian disaring. Sari buah semangka kemudian diuapkan dengan menggunakan thermostat waterbath pada suhu $80^{\circ} \mathrm{C}$ hingga diperoleh ekstrak kental.

Standarisasi Parameter Non Spesifik dan Spesifik Ekstrak Air Buah Semangka

Standarisasi non spesifik meliputi uji kadar abu total, kadar air, kadar abu tidak larut asam, kadar abu larut air. Standarisasi spesifik meliputi uji organoleptis, kadar sari larut air, kadar sari larut etanol.

\section{Uji Sukrosa Secara Kualitatif pada Ekstrak}

Uji sukrosa secara kualitatif menggunakan uji molish. Reagen molisch terdiri dari larutan $\alpha-$ naftol dalam etanol. Pengujian dilakukan dengan cara $2 \mathrm{ml}$ larutan sampel dimasukkan dalam tabung reaksi kemudian ditambahkan 2 tetes reagen molisch dan ditambahkan $5 \mathrm{ml}$ asam sulfat pekat melalui dinding, hasil positif ditandai dengan terbentuknya warna ungu pada larutan. 
Hal yang sama juga dilakukan terhadap berbagai formula sediaan.

\section{Pembuatan Sediaan Krim Pelembab Ekstrak Air} Buah Semangka (Citrullus lanatus)

Fase minyak yaitu asam stearat dan gliseril monostearat dilebur pada suhu $70^{\circ} \mathrm{C}$. Metil paraben dan propil paraben dilarutkan dalam propilen glikol. Fase air yaitu trietanolamin,gliserin,propilen glikol dipanaskan pada suhu $70^{\circ} \mathrm{C}$. Fase minyak dan fase air dicampurkan ke dalam mortir panas kemudian digerus hingga membentuk massa krim. Ekstrak kental buah semangka ditambahkan secara perlahan pada basis krim yang telah terbentuk selanjutnya diaduk hingga homogen. Formula sediaan krim pelembab ekstrak air buah Semangka dapat dilihat pada Tabel 1.

Evaluasi Sediaan Krim Pelembab Ekstrak Air Buah Semangka (Citrullus lanatus)

Evaluasi sediaan krim meliputi uji mutu fisik yang terdiri dari uji organoleptis, $\mathrm{pH}$, homogenitas, viskositas, daya sebar, daya lekat, daya tercucikan air, dan tipe emulsi sediaan (dengan metode metilen blue), Uji efektivitas terdiri dari uji daya melembabkan dengan metode The Sorbtion-Desoption Test (SDT) dan uji daya antioksidan menggunakan metode pengurangan radikal bebas DPPH (2,2-diphenyl-1picrylhydrazyl), uji keamanan sediaan, uji aseptabilitas dan uji stabilitas sediaan.

\section{Metode Analisa Data Statistik}

Data hasil uji dianalisis secara statistik dengan menggunakan software SPSS statistic 17.0. Analisa data antar bets menggunakan metode analisis parametrik independent sample $t$ test dan analisis non parametrik yaitu MannWhitney. Uji antar formula dilakukan pengolahan data menggunakan metode analisis data statistik yang bersifat parametrik dengan menggunakan one way anova $(\alpha=0,05)$ dan non parametrik dengan menggunakan Kruskal-wallis.

Tabel 1. Formula Sediaan Krim Pelembab Ekstrak Air Buah Semangka (Citrullus lanatus)

\begin{tabular}{|c|c|c|c|c|c|c|}
\hline Komposisi & $\begin{array}{c}\text { Formula } \\
1 \\
\end{array}$ & $\begin{array}{c}\text { Formula } \\
2\end{array}$ & $\begin{array}{c}\text { Formula } \\
\mathbf{3} \\
\end{array}$ & $\begin{array}{c}\text { Blangko } \\
1\end{array}$ & $\begin{array}{c}\text { Blangko } \\
2\end{array}$ & Fungsi \\
\hline $\begin{array}{l}\text { Ekstrak Buah } \\
\text { Semangka }\end{array}$ & $10 \%$ & $20 \%$ & $30 \%$ & - & - & Bahan aktif \\
\hline Asam stearat & $12 \%$ & $12 \%$ & $12 \%$ & $12 \%$ & $12 \%$ & $\begin{array}{c}\text { Emulsifying } \\
\text { agent }\end{array}$ \\
\hline Gliserin & $5 \%$ & $5 \%$ & $5 \%$ & $5 \%$ & - & Humektan \\
\hline Propilen Glikol & $3 \%$ & $3 \%$ & $3 \%$ & $3 \%$ & - & $\begin{array}{c}\text { Humektan \& } \\
\text { Oklusif }\end{array}$ \\
\hline Gliseril monostearat & $4 \%$ & $4 \%$ & $4 \%$ & $4 \%$ & $4 \%$ & $\begin{array}{c}\text { Emulgator, } \\
\text { Stiffening agent }\end{array}$ \\
\hline TEA & $1 \%$ & $1 \%$ & $1 \%$ & $1 \%$ & $1 \%$ & $\begin{array}{c}\text { Emulsifying } \\
\text { agent }\end{array}$ \\
\hline Metil paraben & $0,18 \%$ & $0,18 \%$ & $0,18 \%$ & $0,18 \%$ & $0,18 \%$ & Pengawet \\
\hline Propil paraben & $0,02 \%$ & $0,02 \%$ & $0,02 \%$ & $0,02 \%$ & $0,02 \%$ & Pengawet \\
\hline Akuades & Ad $100 \mathrm{ml}$ & Ad $100 \mathrm{ml}$ & Ad $100 \mathrm{ml}$ & $\begin{array}{l}\text { Ad } 100 \\
\text { ml }\end{array}$ & $\begin{array}{l}\text { Ad } 100 \\
\mathrm{ml}\end{array}$ & Pelarut \\
\hline
\end{tabular}

\section{HASIL DAN PEMBAHASAN}

Tujuan dilakukan standarisasi yaitu untuk menjamin kualitas/mutu ketersediaan bahan baku (DirJen POM, 2000). Hasil standarisasi spesifik dan non spesifik pada ekstrak kental buah semangka memberikan hasil yang dapat digunakan sebagai bahan baku utama dalam formulasi sediaan krim pelembab. Hasil standarisasi dapat dilihat pada Tabel 2. Hasil Antioksidan dari ekstrak kental buah semangka dapat dilihat pada Gambar 1.

Hasil uji sukrosa secara kualitatif pada ekstrak menunjukkan hasil yang positif dimana terbentuk larutan berwarna ungu setelah sampel direaksikan dengan asam sulfat dan reagen molisch. Hal tersebut membuktikan bahwa kandungan senyawa aktif yaitu sukrosa, masih terdapat dalam ekstrak setelah melalui proses ekstraksi. Hasil uji sukrosa secara kualitatif dapat dilihat pada Gambar 2.
Pemeriksaan organoleptis sediaan bertujuan untuk melihat bentuk, warna dan bau dari sediaan krim pelembab ekstrak air buah semangka yang dihasilkan. Semua sediaan yang diuji berbentuk krim, berbau khas semangka (F1,F2 dan F3), berbau khas basis (B1 dan B2). Warna sediaan untuk F1 merah muda kecoklatan, F2 dan F3 berwarna merah kecoklatan dan B1 dan B2 berwarna putih karena tidak mengandung ekstrak. Perbedaan warna sediaan tersebut dipengaruhi oleh konsentrasi ekstrak buah semangka yang berbeda pada masing-masing formula. Semakin tinggi konsentrasi ekstrak maka intensitas warna sediaan yang dihasilkan juga semakin tinggi. Hasil pemeriksaan organoleptis sediaan dapat dilihat pada Gambar 3 .

Pemeriksaan $\mathrm{pH}$ sediaan krim pelembab dilakukan untuk melihat derajat keasaman dari sediaan. Apabila sediaan krim memiliki $\mathrm{pH}$ yang terlalu basa maka dapat menyebabkan kulit 
menjadi bersisik, begitupun sebaliknya, apabila sediaan krim memilki pH sediaan yang terlalu asam maka dapat menimbulkan iritasi pada kulit (Djajadisastra, 2004). Spesifikasi untuk nilai $\mathrm{pH}$ sediaan yang diinginkan yaitu dalam rentang 6,0 $\pm 0,5$ (Djajadisastra, 2004). Ketiga formula yang mengandung ekstrak air buah semangka (F1,F2 dan F3) memenuhi spesifikasi yang diinginkan. Analisa statistik antar formula diperoleh nilai F hitung $(980,580)$ lebih besar dari
F tabel $(2,76)$ sehingga dapat disimpulkan bahwa terdapat perbedaan bermakna antar formula. Sediaan yang mengandung ekstrak memiliki nilai $\mathrm{pH}$ yang lebih rendah dari formula blangko (tanpa ekstrak). Hal ini disebabkan oleh $\mathrm{pH}$ ekstrak kental buah semangka yang tergolong asam lemah

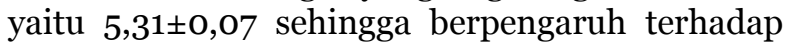
pH sediaan. Hasil pengukuran nilai $\mathrm{pH}$ sediaan dapat dilihat pada Tabel 5 .

Tabel 2. Hasil Standarisasi Ekstrak Buah Semangka (Citrullus lanatus)

\begin{tabular}{llcc}
\hline \multicolumn{1}{c}{ Standarisasi } & \multicolumn{1}{c}{ Jenis Uji } & $\begin{array}{c}\text { Hasil } \\
\text { Pengamatan }\end{array}$ & Persyaratan \\
\hline Non Spesifik & Penetapan kadar air (\%) & $12,49 \pm 0,43$ & $\begin{array}{c}5-30 \% \\
\text { (Voight,1994) }\end{array}$ \\
& Penetapan kadar abu total (\%) & $1,98 \pm 0,25$ & - \\
& Penetapan kadar abu tidak larut asam & $0,24 \pm 0,05$ & - \\
\hline P) & Penetapan kadar abu larut air (\%) & $1,37 \pm 0,22$ & - \\
\hline Organoleptis & Merah & - \\
& - Warna & kecoklatan & - \\
& - Bau & Khas semangka & - \\
& Pemerifik & Semi solida & - \\
\hline
\end{tabular}

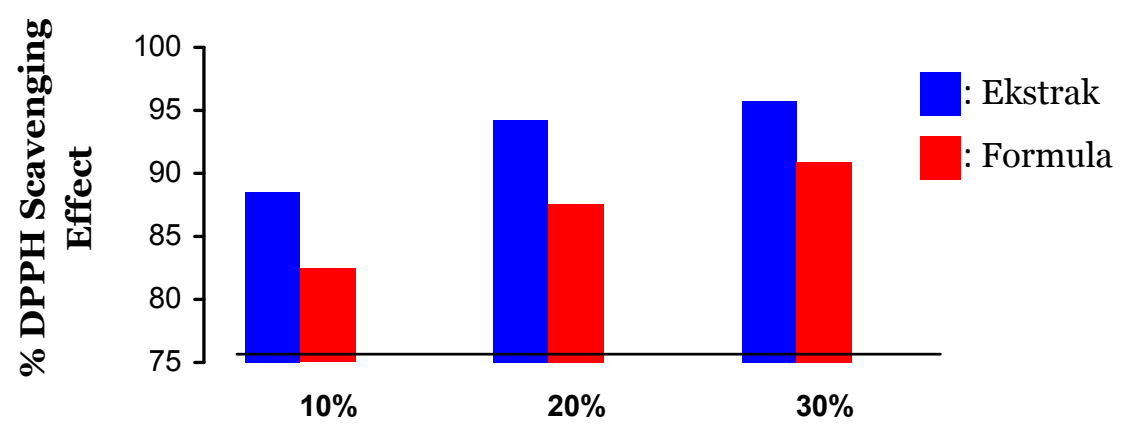

Gambar 1. Hasil \% DPPH scavenging effect ekstrak kental buah semangka (Citrullus lanatus) pada berbagai konsentrasi.

Tabel 3. Hasil Uji Daya Antioksidan Ekstrak Kental Buah Semangka (Citrullus lanatus).

\begin{tabular}{|c|c|c|c|c|c|c|}
\hline \multirow[t]{2}{*}{ Parameter Daya Antioksidan } & \multicolumn{3}{|c|}{ Ekstrak (\%) } & \multicolumn{3}{|c|}{ Formula } \\
\hline & 10 & 20 & 30 & F1 & F2 & F3 \\
\hline$\%$ DPPH Scavenging effect $\left(\bar{x}_{ \pm} \mathbf{S D}\right)$ & $88,51 \pm 0,48$ & $94,25 \pm 12,98$ & $95,72 \pm 9,99$ & $82,44 \pm 5,98$ & $87,56 \pm 3,44$ & $90,91 \pm 4,88$ \\
\hline
\end{tabular}

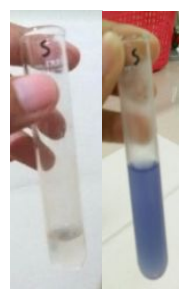

Sukrosa

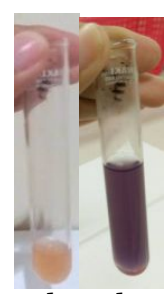

Ekstrak

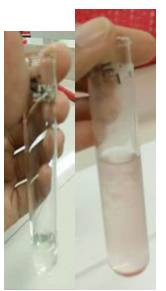

Formula 1 Formula 2 Formula 3

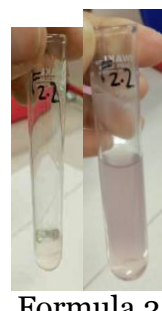

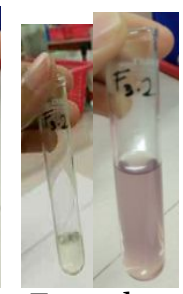

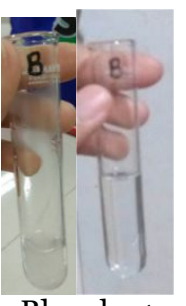

Gambar 2. Hasil pengamatan uji molisch pada sukrosa (pembanding), ekstrak kental buah semangka dan sediaan krim pelembab pada berbagai formula 


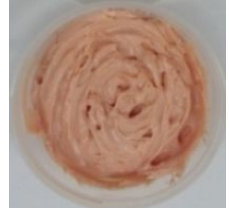

Formula 1

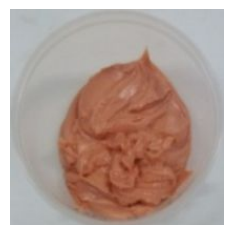

Formula 2

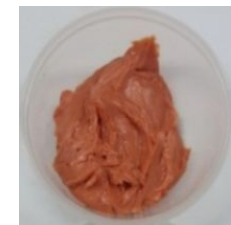

Formula 3

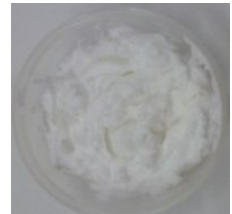

Blangko 1

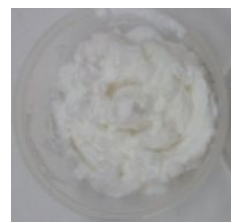

Blangko 2

Gambar 3. Hasil pemeriksaan organoleptis (warna dan bentuk) sediaan krim pelembab ekstrak air buah semangka (Citrullus lanatus)

Pemeriksaan homogenitas sediaan bertujuan untuk melihat dan mengetahui ketercampuran bahan-bahan sediaan krim yang digunakan dengan melihat ada tidaknya butiran kasar pada sediaan. Jika sediaan telah dinyatakan homogen maka dapat diasumsikan bahwa setiap pengaplikasian sediaan akan mengandung kadar zat aktif yang sama sehingga homogenitas sediaan berpengaruh terhadap efektifitas sediaan. Hasil pengamatan menunjukkan bahwa dari semua formula sediaan krim pelembab yang diuji menunjukkan hasil sediaan yang homogen sesuai dengan spesifikasi sediaan yang diinginkan.

Pemeriksaan Viskositas sediaan bertujuan untuk melihat kekentalan dari sediaan krim pelembab yang dihasilkan. Spesifikasi yang diinginkan untuk viskositas sediaan yaitu antara 30.000-700.000 cps (Buhse, 2003). Hasil yang diperoleh memenuhi spesifikasi.Analisa statistik antar formula diperoleh nilai $\mathrm{F}$ hitung $(237,370)$ lebih besar dari $\mathrm{F}$ tabel $(2,76)$ yang menunjukkan adanya perbedaan bermakna antar formula dimana pada peningkatan konsentrasi ekstrak kental buah semangka dapat mempengaruhi nilai viskositas sediaan. Hasil pengukuran viskositas sediaan dapat dilihat pada Tabel 5 .

Pengujian daya sebar sediaan bertujuan untuk melihat kemampuan sediaan untuk menyebar di kulit saat diaplikasikan. Kemampuan penyebaran yang baik maka akan semakin mudah dalam pengaplikasian krim pada kulit (Zulkarnain dan Shovyana, 2013). Spesifikasi daya sebar yang diharapkan yaitu mudah menyebar (diameter penyebaran $=3-7 \mathrm{~cm})$ (Garg et al., 2000). Hasil pengujian daya sebar untuk semua formula memenuhi spesifikasi yang diinginkan. Analisa statistik antar formula diperoleh nilai $\mathrm{F}$ hitung $(70,410)$ lebih besar dari $\mathrm{F}$ tabel $(2,76)$ sehingga dapat disimpulkan bahwa terdapat perbedaan bermakna antar formula. Hal tersebut menunjukkan bahwa peningkatan konsentrasi ekstrak kental buah semangka dalam sediaan mempengaruhi daya sebar sediaan. Hasil pengujian daya sebar dapat dilihat pada Tabel 5 .

Pengukuran daya lekat sediaan bertujuan untuk mengetahui lamanya waktu kontak antara krim dengan kulit. Krim yang baik mampu memberikan waktu kontak yang efektif pada kulit sehingga tujuan dapat tercapai dengan maksimal. Menurut Ulaen dkk (2012), syarat untuk daya lekat pada sediaan topikal adalah tidak kurang dari 4 detik. Spesifikasi nilai daya lekat sediaan yang diharapkan yaitu lekat (waktu lekat $=1-2$ menit). Hasil pengujian daya lekat untuk semua formula yang diuji melebihi spesifikasi yang diinginkan. Hal ini dipengaruhi oleh emulgator yang digunakan yaitu asam stearat dan trietanolamin yang merupakan emulgator anionik. Emulgator anionik memiliki keuntungan untuk berpenetrasi ke kulit dengan baik karena dapat berinteraksi dengan baik terhadap lemak dan protein kulit (Levin and Miller, 2011). Hasil pemeriksaan daya lekat sediaan dapat dilihat pada Tabel 5 .

Pengujian terhadap daya tercucikan air dengan metode buret bertujuan untuk melihat tingkat kemudahan krim untuk dibersihkan (Anggraini, Malik dan Susiladewi, 2011). Sediaan krim o/w dikatakan baik jika mudah tercucikan oleh air (Sahu, Jha and Dubey, 2011). Spesifikasi sediaan untuk nilai uji tercucikan air yaitu mudah tercucikan air (volume air $=10-20 \mathrm{ml}$ ). Hasil pengujian daya tercucikan air untuk formula 2 dan formula 3 memenuhi spesifikasi yang diinginkan. Berdasarkan teori, semakin tinggi daya lekat sediaan maka volume air yang dibutuhkan untuk tercucikan air semakin tinggi pula. Namun, hasil yang diperoleh tidak signifikan dimana formula 3 yang memiliki daya lekat paling tinggi $(15,69 \pm 0,51$ menit), membutuhkan air dengan volume paling rendah untuk uji kemudahan tercucikan air $(10,195 \pm 0,39 \mathrm{ml})$. Hal ini dipengaruhi oleh kandungan gula yang tinggi di dalam ekstrak dimana gula memiliki sifat higroskopis yang mampu menarik air dari lingkungan sehingga semakin tinggi konsentrasi ekstrak dalam sediaan maka daya tercucikan air sediaan semakin tinggi (Kitts, 2010). Hasil pemeriksaan daya tercucikan air sediaan dapat dilihat pada Tabel 5 .

Pemeriksaan tipe emulsi sediaan dilakukan untuk melihat tipe emulsi dari sediaan krim yang terdiri dari emulsi minyak dalam air atau emulsi air dalam minyak (Wedana, Leliqia dan Arisanti, 2013). Hasil pengujian tipe emulsi menunjukkan bahwa semua formula sediaan krim pelembab yang diuji memiliki tipe emulsi minyak dalam air sesuai dengan spesifikasi yang diinginkan.

Uji daya melembabkan sediaan pelembab ekstrak air buah semangka dilakukan dengan menggunakan metode gravimetri dengan parameter nilai (AUC) total untuk melihat kemampuan sediaan krim pelembab dalam mempertahankan hidrasi kulit (Baumann, 2002). 
Hasil yang diperoleh memenuhi spesifikasi yang diinginkan. Analisa statistik antar formula diperoleh nilai $\mathrm{F}$ hitung $(119,879)$ lebih besar dari $\mathrm{F}$ tabel $(2,76)$ sehingga dapat disimpulkan bahwa terdapat perbedaan bermakna antar formula. Pada hasil uji efektivitas melembabkan, dengan nilai [AUC]total yang semakin kecil, dapat dikatakan bahwa sediaan mempunyai efek melembabkan yang tinggi dimana semakin kecil nilai [AUC]total yang diperoleh menunjukkan kemampuan krim untuk menahan penguapan air dari kulit. Peningkatan konsentrasi ekstrak pada sediaan menurunkan nilai [AUC]total. Hal tersebut menunjukan bahwa peningkatan konsentrasi ekstrak kental buah semangka mempengaruhi daya melembabkan sediaan. Hasil uji daya melembabkan dapat dilihat pada Tabel 4 dan Gambar 4.

Uji daya antioksidan sediaan dengan metode DPPH , dilakukan untuk melihat aktivitas antioksidan buah semangka setelah diformulasi menjadi sediaan krim sehingga diperoleh suatu sediaan yang mampu melembabkan sekaligus melindungi kulit dari efek radikal bebas. Spesifikasi yang diharapkan untuk nilai daya antioksidan sediaan yaitu tidak berbeda bermakna dengan daya antioksidan ekstrak sehingga dapat diasumsikan kemampuan sediaan dalam menangkal radikal bebas untuk meningkatkan efektivitas sediaan akan sama dengan ekstrak sebelum diformulasi menjadi sediaan krim.

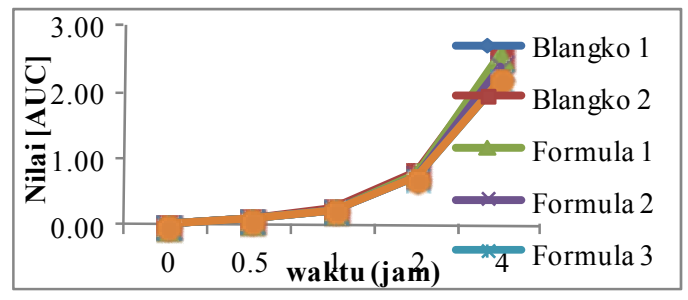

Gambar 4. Grafik yang menunjukkan nilai [AUC]total terhadap waktu sediaan pada berbagai formula.

Analisa statistik antar formula dan sediaan dengan konsentrasi yang sama menunjukan hasil yang tidak berbeda bermakna. Hasil yang diperoleh sesuai dengan spesifikasi sediaan yang diinginkan. Sedangkan berdasarkan nilai daya antioksidan, maka peningkatan konsentrasi ekstrak menyebabkan peningkatan daya antioksidan serta daya melembabkan. Hasil uji daya antioksidan pada ekstrak dapat dilihat pada Tabel 3 dan Gambar 1. Hasil uji daya antioksidan sediaan dapat dilihat pada Tabel 3 dan Gambar 5 .

Tabel 4. Nilai Efektivitas Krim Pelembab Ekstrak Buah Semangka (Citrullus lanatus) Nilai [AUC $]^{t_{\text {tn-1 }}}$

\begin{tabular}{ccccccccccc}
\hline $\begin{array}{c}\text { Waktu } \\
\text { (jam) }\end{array}$ & \multicolumn{2}{c}{ F1 } & \multicolumn{2}{c}{ F2 } & \multicolumn{2}{c}{ F3 } & \multicolumn{2}{c}{ B1 } & \multicolumn{2}{c}{ B2 } \\
\hline 0 & 0,00 & 0,00 & 0,00 & 0,00 & 0,00 & 0,00 & 0,00 & 0,00 & 0,00 & 0,00 \\
0,5 & 0,08 & 0,06 & 0,07 & 0,07 & 0,05 & 0,06 & 0,09 & 0,08 & 0,10 & 0,09 \\
1 & 0,21 & 0,18 & 0,19 & 0,20 & 0,16 & 0,18 & 0,22 & 0,22 & 0,26 & 0,23 \\
2 & 0,70 & 0,64 & 0,63 & 0,67 & 0,61 & 0,64 & 0,70 & 0,73 & 0,83 & 0,76 \\
4 & 2,28 & 2,22 & 2,10 & 2,12 & 2,02 & 2,14 & 2,15 & 2,26 & 2,63 & 2,39 \\
[AUC] & & & & & & & & & & \\
total & $\mathbf{3 , 1 9} \pm \mathbf{o , 1 1}$ & $\mathbf{3 , 0 2} \pm \mathbf{0 , 0 5}$ & $\mathbf{2 , 9 3} \pm \mathbf{0 , 1 2}$ & $\mathbf{3 , 2 3} \pm \mathbf{0 , 1 0}$ & $\mathbf{3 , 6 4} \pm \mathbf{0 , 2 4}$ \\
\hline
\end{tabular}

Uji iritasi dilakukan untuk mengetahui keamanan sediaan yang ditimbulkan dari sediaan saat digunakan pada kulit. Uji iritasi dilakukan terhadap 10 orang panelis. Sediaan yang diharapkan untuk uji iritasi yaitu tidak mengiritasi. Hasil uji iritasi menunjukkan bahwa semua formula tidak menimbulkan iritasi kulit saat diaplikasikan.

Uji Aseptabilitas dilakukan dengan tujuan untuk mengetahui tingkat kesukaan panelis terhadap sediaan. Spesifikasi yang diharapkan untuk uji aseptabilitas yaitu suka. Hasil pengujian diperoleh 2 dari 10 orang panelis kurang menyukai formula 1 dengan alasan sedikit terasa lengket di kulit sehingga kurang nyaman saat diaplikasikan. Analisa statistik pengujian aseptabilitas sediaan antar formula dengan analisa kruskal wallis menunjukkan bahwa chisquare hitung (16.500) > chi-square tabel $(16,919)$ sehingga terdapat perbedaan bermakna untuk antar formula.

Pengujian stabilitas sediaan yang dilakukan yaitu uji sabilitas dipercepat yang terdiri dari cycling test, uji sentrifugasi dan pengujian pada suhu kamar. Uji sentrifugasi merupakan perlakuan yang sama dengan adanya gaya gravitasi selama satu tahun dan diamati ada tidaknya pemisahan fase. Hasil pengujian sentrifugasi menunjukan bahwa semua sediaan stabil dan tidak terjadi pemisahan fase setelah disentrifuse selama 30 menit. Pengujian pada suhu kamar, dilakukan dengan cara sediaan disimpan pada suhu kamar selama 4 minggu dan diamati perubahan organoleptis, $\mathrm{pH}$, dan viskositas setiap minggu. Hasil pengamatan organoleptis tiap minggu menunjukan tidak adanya perubahan pada warna baud an bentuk sediaan. Nilai $\mathrm{pH}$ dan viskositas sediaan selama penyimpanan selama 4 minggu untuk formula 1 , formula 2 dan formula 3 masih masuk dalam rentang spesifikasi yang diinginkan sehingga sediaan masih dapat diterima. Hasil pengamatan stabilitas sediaan dapat dilihat pada Tabel 3 dan Gambar 3.

Hasil penelitian menunjukan bahwa peningkatan konsentrasi ekstrak kental buah semangka berpengaruh secara signifikan $(\mathrm{P}<0,05)$ terhadap organoleptis, $\mathrm{pH}$, viskositas, daya sebar, 
daya lekat, daya tercucikan air, daya melembabkan, aktivitas antioksidan dan aseptabilitas. Sediaan yang terbaik adalah sediaan dengan konsentrasi ekstrak 30\% (Formula 3).

Tabel 5. Hasil Evaluasi Sediaan Krim Pelembab Ekstrak Air Buah Semangka (Citrullus lanatus)

\begin{tabular}{|c|c|c|c|c|c|c|}
\hline Uji & Formula 1 & Formula 2 & Formula 3 & Blangko 1 & Blangko 2 & Spesifikasi \\
\hline \multicolumn{7}{|l|}{$\begin{array}{l}\text { Mutu Fisik } \\
\text { 1. Organoleptis }\end{array}$} \\
\hline - Bentuk & Krim & Krim & Krim & Krim & Krim & Krim \\
\hline - Warna & $\begin{array}{l}\text { Merah muda } \\
\text { kecoklatan }\end{array}$ & Merah Kecoklatan & $\begin{array}{c}\text { Merah } \\
\text { Kecoklatan }\end{array}$ & Putih & Putih & $\begin{array}{c}\text { Merah muda } \\
\text { Kecoklatan-merah } \\
\text { kecoklatan }\end{array}$ \\
\hline - Bau & Khas & Khas & Khas & Khas & Khas & Khas \\
\hline 2. $\mathrm{pH}$ & $6,05 \pm 0,023$ & $5,99 \pm 0,026$ & $5,87 \pm 0,011$ & $6,98 \pm 0,087$ & $6,95 \pm 0,02$ & $6,0 \pm 0,5$ \\
\hline 3. Homogenitas & Homogen & Homogen & Homogen & Homogen & Homogen & Homogen \\
\hline 4. Viskositas & $\begin{array}{c}35716,67 \pm \\
1259,63\end{array}$ & $\begin{array}{c}62373,33 \pm \\
2985,85\end{array}$ & $\begin{array}{c}64438,33 \pm \\
4400,59\end{array}$ & $\begin{array}{c}34818,33 \pm \\
864,51\end{array}$ & $\begin{array}{c}27370,67 \pm \\
15831,33\end{array}$ & $30000-700000 \mathrm{cps}$ \\
\hline 5. Daya Sebar & $4,85 \pm 0,00$ & $3,18 \pm 0,09$ & $3,37 \pm 0,11$ & $6,20 \pm 0,42$ & $6,46 \pm 0,30$ & $\begin{array}{l}\text { Mudah menyebar } \\
\text { (diameter: } 3-7 \mathrm{~cm} \text { ) }\end{array}$ \\
\hline 6. Daya Lekat & $5,93 \pm 0,51$ & $9,17 \pm 0,15$ & $15,69 \pm 0,51$ & $4,45 \pm 0,05$ & $4,23 \pm 0,10$ & $\begin{array}{l}\text { Lekat (waktu : 1-2 } \\
\text { menit) }\end{array}$ \\
\hline $\begin{array}{l}\text { 7. Kemudahan } \\
\text { Tercucikan Air }\end{array}$ & $22,58 \pm 1,39$ & $11,02 \pm 022$ & $10,19 \pm 0,39$ & $24,9 \pm 0,24$ & $27,37 \pm 0,85$ & $\begin{array}{l}\text { Mudah tercucikan } \\
\text { air (volume air : 10- } \\
20 \mathrm{ml} \text { ) }\end{array}$ \\
\hline $\begin{array}{l}\text { 8. Tipe emulsi } \\
\text { Efektivitas }\end{array}$ & $\mathrm{O} / \mathrm{W}$ & $\mathrm{O} / \mathrm{W}$ & $\mathrm{O} / \mathrm{W}$ & $\mathrm{O} / \mathrm{W}$ & $\mathrm{O} / \mathrm{W}$ & $\mathrm{O} / \mathrm{W}$ \\
\hline $\begin{array}{l}\text { 1. Daya } \\
\text { Melembabkan } \\
\text { ([AUC]total) }\end{array}$ & $3,19 \pm 0,11$ & $3,02 \pm 0,05$ & $2,93 \pm 0,12$ & $3,23 \pm 0,10$ & $3,64 \pm 0,24$ & $\begin{array}{l}\text { [AUC]total formula } \\
\text { lebih kecil dari } \\
\text { [AUC] total formula } \\
\text { blangko. }\end{array}$ \\
\hline $\begin{array}{l}\text { 2. Daya } \\
\text { Antioksidan } \\
\text { (\% DPPH } \\
\text { Scavenging } \\
\text { effect) }\end{array}$ & $82,44 \pm 5,98$ & $87,56 \pm 3,44$ & $90,91 \pm 4,88$ & $0,00 \pm 0,00$ & $0,00 \pm 0,00$ & $\begin{array}{l}\text { Daya antioksidan } \\
\text { sediaan tidak } \\
\text { berbeda bermakna } \\
\text { dengan daya } \\
\text { antioksidan ekstrak. }\end{array}$ \\
\hline $\begin{array}{l}\text { Keamanan } \\
\text { Iritasi } \\
\text { Stabilitas }\end{array}$ & $\begin{array}{c}\text { Tidak } \\
\text { Mengiritasi }\end{array}$ & $\begin{array}{c}\text { Tidak } \\
\text { Mengiritasi }\end{array}$ & $\begin{array}{c}\text { Tidak } \\
\text { Mengiritasi }\end{array}$ & $\begin{array}{c}\text { Tidak } \\
\text { Mengiritasi }\end{array}$ & $\begin{array}{c}\text { Tidak } \\
\text { Mengiritasi }\end{array}$ & Tidak Mengiritasi \\
\hline $\begin{array}{l}\text { 1. Penyimpana } \\
\text { n pada Suhu } \\
\text { Kamar }\end{array}$ & Stabil & stabil & stabil & stabil & stabil & $\begin{array}{l}\text { Stabil secara } \\
\text { organoleptis, } \mathrm{pH} \text { dan } \\
\text { viskositas }\end{array}$ \\
\hline 2. Sentrifugasi & Stabil & Stabil & Stabil & Stabil & Stabil & $\begin{array}{l}\text { Stabil (Tidak Terjadi } \\
\text { Pemisahan Fase) }\end{array}$ \\
\hline 3. Cycling test & Stabil & Stabil & Stabil & Stabil & Stabil & $\begin{array}{l}\text { Stabil (Tidak Terjadi } \\
\text { Pemisahan Fase) }\end{array}$ \\
\hline
\end{tabular}

\section{KESIMPULAN}

Berdasarkan hasil penelitian dapat dinyatakan bahwa peningkatan konsentrasi ekstrak kental buah semangka dalam sediaan berpengaruh secara signifikan $(\mathrm{P}<0,05)$ terhadap hasil evaluasi sediaan yaitu uji organoleptis, nilai $\mathrm{pH}$, nilai viskositas, daya sebar, daya lekat, daya tercucikan air, daya melembabkan, aktivitas

\section{DAFTAR PUSTAKA}

Anggraini, D., Malik, M., dan Susiladewi, M. 2011, Formulasi Krim Serbuk Getah Buah Pepaya (Carica papaya L) Sebagai Anti Jerawat, Jurnal Fakultas Farmasi Universitas Andalas, Riau.

Baumann, L. 2002, Cosmetic Dermatology Principles and Practice, The McGraw-Hill Companies Inc, New York, USA.

Buhse, L. 2003, 'Presented at the Advisory Committee for Pharmaceutical Science Meeting On March 12', Diaksespada 10 Desember 2015, http:///www.fda.gov/ohrms/dockets/ ac/03/slides/3926S1 11 Buhse.ppt. antioksidan dan kesukaan. Sediaan yang memiliki uji organoleptis, nilai $\mathrm{pH}$, nilai viskositas, daya sebar, daya lekat, daya tercucikan air, daya melembabkan, aktivitas antioksidan dan aseptabilitas terbaik adalah sediaan dengan konsentrasi ekstrak 30\% (Formula 3). 
Levin J, Miller,R. 2011, "A Guide to the Ingredients and Potential Benefits of Over-the-Counter Cleansers and Moisturizers for Rosacea Patients", J Clin Aesthet Dermatol, 4(8):31-49.

Liu, J., Guo, S., He, H., Zhang, H., Gong, G., Ren, Y., and Xu, Y., 2013, Dynamic characteristics of sugar accumulation and related enzyme activities in sweet and non-sweet watermelon fruits, Acta Physiol Plant, (35):3213-3222.

Lubis, E.S., Lubis, L.S., dan Reveny, J. 2012, Pelembab Kulit Alami Dari Sari Buah Jeruk Bali [Citrus maxima (Burm.) Osbeck], Journal of Pharmaceutics and Pharmacology, 1(2):104-111.

Rawlings, A.V., Harding, C.R., Watkinson, A., and Scott, I.R., 2000, Dry and Skin Condition, Skin Moisturization, Marcel Dekker Inc, New York, p 120.

Sahu, A.N., Jha, S., and Dubey, S.D. 2011, Formulation and Evaluation of Curcuminoid Based Herbal Face Cream, IndoGlobal Journal of Pharmaceutical Sciences, pp 77-84.

Simion, F.A., Abrutyn, E.S., Draelos, Z.D. 2005, Ability of moisturizers to reduce dry skin and irritation and to prevent their return, J. Cosmet.Sci., (56):427-444.
Ulaen, Selfie, P.J., Banne, Yos Suatan dan Ririn, A. 2012, Pembuatan Salep Anti Jerawat dari Ekstrak Rimpang Temulawak (Curcuma xanthorrhiza Roxb.), Jurnal Ilmiah Farmasi, 3(2): 45-49.

United States Department of Agriculture, 2003, National Nutrient Database for Standard Reference Release 28, Diakses pada 30 Januari 2016, http://www.ars.usda.gov/ba/bhnrc/ndl.

Wijaya, A. 1996, Radikal Bebas dan Parameter Status Antioksidan, Forum Diagnosticum I, pp 1-4.

Wedana, J.S., Leliqia, N.P.E., danArisanti, C.I.S. 2013, 'Optimasi komposisi span 6o dan tween 80 sebagai emulgator terhadap stabilitas fisik dalam formulasi cold cream ekstrak kulit buah manggis (Garcinia mangostana L.)', Skripsi, SarjanaFarmasi, UniversitasUdayana, Bali.

Voegeli, D. 2007, The role of emollient in the care of patient with dry skin, Nursing Standard, pp 62-68.

Zulkarnain, A.K. dan Shovyana, H.H. 2013, Stabilitas fisik dan aktivitas krim w/o ekstrak etanolik buah mahkota dewa (Phaleria macrocarpha (scheff.) Boerl,) sebagai tabir surya, Traditional Medicine Journal, 18(2), pp 109-113. 